\title{
Differing planes of pre- and postweaning phase nutrition in Holstein heifers: II. Effects on circulating leptin, luteinizing hormone, and age at puberty
}

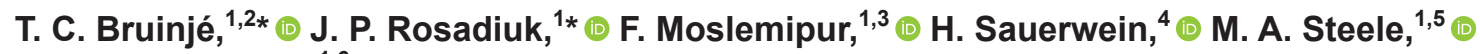 \\ and D. J. Ambrose ${ }^{1,6}+$ (1) \\ ${ }^{1}$ Department of Agricultural, Food and Nutritional Science, University of Alberta, Edmonton, AB, Canada, T6G 2P5 \\ ${ }^{2}$ Department of Population Medicine, University of Guelph, Guelph, ON, Canada, N1G 2W1 \\ ${ }^{3}$ Department of Animal Science, Gonbad Kavoos University, PO Box 163, Golestan, Iran, 49717-99151 \\ ${ }^{4}$ Physiology and Hygiene Unit, Institute of Animal Science, University of Bonn, 53113 Bonn, Germany \\ ${ }^{5}$ Department of Animal Biosciences, University of Guelph, Guelph, ON, Canada, N1G 2W1 \\ ${ }^{6}$ Livestock Research Branch, Alberta Agriculture and Forestry, Edmonton, AB, Canada, T6H 5T6
}

\section{ABSTRACT}

The objectives were to investigate the effects of differing planes of pre- and postweaning nutrition on prepubertal serum leptin concentrations, LH profiles, and age at puberty in Holstein heifers. Thirty-six Holstein calves were randomly assigned to either a low $(5 \mathrm{~L})$ or high $(10 \mathrm{~L}$ of whole milk/d) preweaning plane of nutrition from 1 to $7 \mathrm{wk}$ of age, a transition diet (a dry total mixed ration with $85 \%$ of concentrate) from wk 8 to 10 , and to either a low $(70 \%)$ or high $(85 \%$ of concentrate dry total mixed ration) postweaning plane from 11 to 25 wk of age. Serum leptin concentrations were measured every 2 wk from 1 to 25 wk of age, and LH profiles were determined both at wk 15 and 25 based on sequential blood samples taken every 12 min over $10 \mathrm{~h}$. Starting at $26 \mathrm{wk}$ of age, ovaries were examined weekly by transrectal ultrasonography until first ovulation (puberty) was confirmed. Heifers that received the high preweaning plane diet had greater mean ( \pm standard error; SE) leptin concentrations during the preweaning phase than those fed the low plane $(2.9 \pm 0.1$ vs. $2.6 \pm 0.1 \mathrm{ng} / \mathrm{mL})$. During the postweaning phase, mean circulating leptin was greater in heifers fed the high compared with the low postweaning diet $[3.2 \mathrm{ng} / \mathrm{mL}$ (95\% confidence interval; $\mathrm{CI}=2.7$ to 3.4 ) vs. $2.5 \mathrm{ng} / \mathrm{mL}(95 \% \mathrm{CI}=2.3$ to 2.8$)]$. Mean ( $\pm \mathrm{SE}$ ) amplitude $(2.1 \pm 0.1$ vs. $1.7 \pm 0.1 \mathrm{ng} / \mathrm{mL})$, peak $(2.2$ \pm 0.1 vs. $1.8 \pm 0.1 \mathrm{ng} / \mathrm{mL})$, and duration $(35.6 \pm 2.1$ vs. $28.7 \pm 2.0 \mathrm{~min}$ ) of $\mathrm{LH}$ pulses assessed at wk 15 were greater in heifers offered the high than those offered the low preweaning plane, but no nutritional effects were observed on LH pulses at wk 25. Mean $( \pm$ SE) age at puberty was $250 \pm 9 \mathrm{~d}$ and was not influenced by

Received April 29, 2020

Accepted July 31, 2020.

*These authors contributed equally to this work.

†Corresponding author: dambrose@ualberta.ca planes of nutrition. However, the likelihood of attaining puberty by 30 wk of age was greater (hazard ratio $=3.8 ; 95 \% \mathrm{CI}=1.0$ to 14.4 ) in heifers fed the high postweaning plane compared with the low plane. Heifers achieving puberty by $30 \mathrm{wk}$ also had greater leptin concentrations from wk 1 to 25 , whereas for every $1 \mathrm{ng} /$ $\mathrm{mL}$ increase in circulating leptin at wk 15 and 25, days to puberty were estimated to decrease by $22 \mathrm{~d}(95 \%$ CI $=1$ to 44$)$ and $13 \mathrm{~d}(95 \% \mathrm{CI}=1$ to 24$)$, respectively. Increasing the preweaning plane from 5 to $10 \mathrm{~L} / \mathrm{d}$ of whole milk increased serum leptin concentrations at wk 1,3 , and 5 and $\mathrm{LH}$ pulse amplitude, peak, and duration at wk 15. Increasing the postweaning plane from 70 to $85 \%$ of concentrate resulted in greater circulating leptin concentrations, which may be linked to an earlier onset of puberty.

Key words: dairy calf, early-life nutrition, physiology, reproduction

\section{INTRODUCTION}

In Holstein heifers, the optimal age at first calving associated with improved lifetime productivity and overall economic return is between 22 and 24 mo (Heinrichs et al., 2017), requiring a successful conception to occur between approximately 13 and 15 mo of age. However, the age at first calving averages approximately $25 \mathrm{mo}$ in the United States (USDA, 2009), and half of dairy herds in Canada have an average age at first calving of over 25 mo (Canwest DHI, 2018). An increased age at first calving might result in increased overall costs associated with heifer raising until their first lactation. It has been reported that heifers with an early attainment of puberty, as a result of an increased preweaning plane of nutrition and greater daily BW gain, were also younger at first breeding, at conception, and at first calving, and had greater future productivity than their counterparts who received a lower plane (Davis Rincker et al., 2011). Likewise, increasing the plane of nutrition 
in the postweaning phase was associated with improved prepubertal reproductive tract development (Bruinjé et al., 2019), reduced age at puberty (Chelikani et al., 2003) and at first breeding (Radcliff et al., 2000), and increased future productivity (Shamay et al., 2005). As heifers bred after multiple spontaneous estrous cycles are more fertile than those bred on their first cycle (Byerley et al., 1987), those with an early onset of puberty are more likely to have improved reproductive performance when they reach the optimal breeding age.

In recent years, a greater understanding of the mechanisms related to nutritional status that regulate the maturation of the hypothalamic-pituitary-ovarian axis and onset of puberty in heifers has been achieved (Perry, 2016). For instance, Freetly et al. (2011) evaluated beef heifers of differing breeds and concluded that the percentage of mature $\mathrm{BW}$ attained is a more appropriate predictor of age at puberty than absolute BW. The composition of the body at pubertal onset is also important as adipose tissue secretes leptin, a key hormone linking nutritional status to sexual maturation and fertility in heifers (Zieba et al., 2004; Perry, 2016). Through its relationship with nutritional status, leptin regulates gonadotropin secretion by modulating the hypothalamic-pituitary axis; nevertheless, previous studies concluded that an increase in leptin alone is not strictly associated with attainment of sexual maturation in prepubertal heifers (Block et al., 2003; Zieba et al., 2004; Chelikani et al., 2009). The relationship between leptin and onset of puberty seems to be related to the nutritional status around pubertal age. Beef heifers attaining early puberty as a result of increasing the postweaning nutritional plane also had increased frequency of LH pulses starting 2 mo before puberty onset (Gasser et al., 2006b). This suggests that characteristics of LH profiles during the prepubertal phase might be a potential indicator of sexual development in heifers.

Several studies have examined the relationship between early-life nutrition and reproductive development in dairy heifers (Chelikani et al., 2003, 2009; Shamay et al., 2005; Davis Rincker et al., 2011; Bruinjé et al., 2019). However, the relationships of pre- and postweaning nutrition with physiology related to onset of puberty are yet to be fully understood. Understanding such associations are particularly relevant to dairy heifers, as early-life nutrition has become a topic of increasing interest due to its effect on future productivity (Khan et al., 2011). Furthermore, a possible interaction between pre- and postweaning diets and their effects on sexual development warrant further investigation as past research has focused on one phase or the other. Therefore, the objectives of this study were to determine the effects of pre- and postweaning planes of nu- trition, with different energy and protein contents, on prepubertal serum leptin concentrations, LH profiles, and age at puberty in Holstein heifers. The hypotheses were that increasing pre- and postweaning planes of nutrition would result in greater leptin concentrations during both phases, enhanced LH pulses, and an earlier onset of puberty.

\section{MATERIALS AND METHODS}

\section{Animals and Planes of Nutrition}

Study procedures were approved by the Animal Care and Use Committee for Livestock at the University of Alberta (AUP \#00001553) and heifers were cared for according to standards from the Canadian Council of Animal Care (Ottawa, ON, Canada).

The study enrolled 36 Holstein heifer calves born between February and August 2017 at the Dairy Research and Technology Centre (University of Alberta, Edmonton, AB, Canada). Heifers were born with an average $\mathrm{BW}( \pm \mathrm{SD})$ of $39.1 \pm 3.5 \mathrm{~kg}$ and were preassigned to randomly receive 1 of 2 preweaning dietary treatments [low $(\mathrm{n}=18)$ or high $(\mathrm{n}=18)]$ and 1 of 2 postweaning dietary treatments [low $(\mathrm{n}=18)$ or high $(\mathrm{n}=18)]$ as further described. Based on previous reports (Chelikani et al., 2003; Davis Rincker et al., 2011), an estimated sample size of at least 12 heifers per pre- and postweaning dietary treatment groups was required to detect a difference in age at puberty and in postweaning leptin concentrations with power of $80 \%$ and $\alpha$ of 0.05 . For every 4 calves born, allocation of treatments occurred by sequentially drawing, out of a hat, 1 of the 4 combinations of pre- and postweaning diets [low preweaning, low postweaning diets $(\mathrm{n}=9)$; high preweaning, low postweaning diets $(\mathrm{n}=9)$; low preweaning, high postweaning diets $(\mathrm{n}=9)$; and high preweaning, high postweaning diets $(\mathrm{n}=9)]$. Within each treatment group, calves were similarly distributed among season of birth (winter, spring, or summer), dam parity (primiparous or multiparous), and category of calving difficulty (assisted or unassisted).

Details of the study protocols and experimental design related to nutritional and housing management of the heifers used in this study have been described in a companion paper (Rosadiuk et al., 2020). Calves were fed $2 \mathrm{~L}$ of reconstituted powdered colostrum with a minimum of $60 \mathrm{~g} / \mathrm{L}$ IgG (Headstart Bovine Dried Colostrum, The Saskatoon Colostrum Company, Saskatoon, SK, Canada) within $2 \mathrm{~h}$ after birth, followed by 3 additional meals of $2 \mathrm{~L}$ of whole pasteurized colostrum with a minimum of $50 \mathrm{~g} / \mathrm{L} \operatorname{IgG}$ approximately at 8 , 16 , and $24 \mathrm{~h}$ after the first feeding. Thereafter, heifers received whole milk $(24.8 \% \mathrm{CP}, 30.3 \%$ crude fat, 4.6 
Mcal of ME $/ \mathrm{kg}$ of $\mathrm{DM}$ ) as either a low preweaning diet (5 L of whole milk daily; $2.5 \mathrm{~L}$ meals at 0615 and 1630 h) or a high preweaning diet (10 L of whole milk daily; 2.5-L meals at $0615,1130,1630$, and $2200 \mathrm{~h}$ ) until 21 $\pm 1 \mathrm{~d}$ of age (CalfRail, Förster-Technik GmbH, Engen, Germany). Heifers had ad libitum access to water at all times and free access to a textured starter/concentrate (22.4\% CP, $7.6 \%$ crude fiber, $22.3 \%$ starch, $2.6 \mathrm{Mcal} /$ kg ME of DM; Optivia Rumimax, Trouw Nutrition, Guelph, ON, Canada) from $7 \pm 1$ to $21 \pm 1 \mathrm{~d}$. Heifers were then moved to a group pen and fed the same preweaning plane of nutrition with a stationary automated feeder (CF1000+, DeLaval Canada, Peterborough, ON, Canada), with ad libitum access to starter/concentrate in BioControl bulks (BioControl, Rakkestad, Norway) and straw (Skyline Harvest, Blumenort, MB, Canada). Heifers were weaned on d 60 after a 10-d weaning transition with a $10 \%$ daily decrease in the total milk fed (Khan et al., 2016).

After weaning, calves had ad libitum access to concentrate and straw for $5 \mathrm{~d}$ and received a transition dry TMR with $85 \%$ concentrate and $15 \%$ chopped straw by weight until approximately 10 wk of age, when heifers were moved to an outdoor group pen and assigned to individual automated feed bunks (Calan Broadbent Feeding System, American Calan Inc., Northwood, $\mathrm{NH})$. Starting at wk $11(\sim \mathrm{d} 80)$, heifers in the low postweaning dietary group received a diet with 70:30 concentrate:straw ratio dry TMR, whereas high postweaning heifers continued to be fed 85:15 concentrate: straw diet until wk $25(\sim \mathrm{d} 180)$. The postweaning feeding schemes were based on a previous study (Groen et al., 2015) that compared similar dietary treatments from 17 to 23 wk of age and reported increased DMI and ADG in calves fed more concentrate (85 vs. $70 \%$ of dry TMR). Diet composition of both pre- and postweaning planes of nutrition are presented in Table 1 . At wk 26 of age, all heifers were moved to an adjacent paddock and fed a common diet of free-choice alfalfa blend hay and $2 \mathrm{~kg} / \mathrm{d}$ per heifer of a commercial ration with $15.4 \% \mathrm{CP}, 38.2 \%$ starch, and $1.7 \mathrm{Mcal} / \mathrm{kg}$ of ME (Advantage 4, Trouw Nutrition, Guelph, ON, Canada) until the end of the study. A schematic representation of the study design timeline is presented in Figure 1.

\section{Blood Sampling for Leptin and Luteinizing Hormone}

Leptin. Throughout the treatment periods, blood samples were harvested via jugular venipuncture into silicon coated tubes (BD Vacutainer, Franklin Lakes, $\mathrm{NJ})$ every $2 \mathrm{wk}$, approximately $2.5 \mathrm{~h}$ after feeding. Immediately after collection, samples were left undisturbed for approximately $2 \mathrm{~h}$ at room temperature, centrifuged $\left(20 \mathrm{~min}\right.$ at $4^{\circ} \mathrm{C}$ and $\left.3,000 \times g\right)$ and stored at $-20^{\circ} \mathrm{C}$ until analysis. Serum leptin concentrations were determined by competitive enzyme immunoassay as described by Sauerwein et al. (2004). The inter- and intraassay coefficients of variation were $9.1 \%$ and $8.8 \%$, respectively.

Luteinizing Hormone. At both 15 wk $(105 \pm 6$ d) and $25 \mathrm{wk}(177 \pm 6 \mathrm{~d})$ of age, heifers were brought indoors the evening before the day of sample collection for placement of a jugular catheter and housed in individual but contiguous pens $(3.0 \times 3.6 \mathrm{~m}$ each $)$ for a total of $26 \mathrm{~h}$ until the end of sample collection. To minimize any psychosocial stress, heifers were moved as a group and kept together while preparing for placement of jugular catheters. Although individually housed, heifers were able to make social contact (auditory, visual, and limited physical contact through bars of adjacent pens) with peers. Heifers were completely free to move around within the pen and had more than $12 \mathrm{~h}$ to adapt to the indoor surroundings and remained undisturbed overnight. Pens were bedded with wood

Table 1. Composition of the pre- and postweaning planes of nutrition (low and high) fed to 36 Holstein heifers

\begin{tabular}{lrr}
\hline & $\begin{array}{c}\text { Low } \\
(\mathrm{n}=18)\end{array}$ & $\begin{array}{c}\text { High } \\
(\mathrm{n}=18)\end{array}$ \\
Item & & \\
& & \\
Preweaning phase $^{1}$ & 5.0 & 10.0 \\
Amount of pasteurized whole milk fed (L/d) & & \\
Chemical composition of whole milk & 24.8 & 24.8 \\
CP (\% of DM) & 30.3 & 30.3 \\
Crude fat (\% of DM) & 4.6 & 4.6 \\
ME (Mcal/kg of DM) & & \\
Chemical composition of starter/concentrate & 22.4 & 22.4 \\
CP (\% of DM) & 7.6 & 7.6 \\
Crude fiber (\% of DM) & 22.3 & 22.3 \\
Starch (\% of DM) & 2.6 & 2.6 \\
ME (Mcal/kg of DM) & & \\
Chemical composition of straw & 4.6 & 4.6 \\
CP (\% of DM) & 71.6 & 71.6 \\
NDF (\% of DM) & 1.6 & 1.6 \\
ME (Mcal/kg of DM) & & \\
Postweaning phase ${ }^{2}$ & & \\
Ingredient (\% of DM) & 70.0 & 85.0 \\
Concentrate & 46.5 & 56.5 \\
Rumimax pellets ${ }^{3}$ & 10.8 & 13.1 \\
Beet pulp pellets & 10.5 & 12.8 \\
Rolled corn & 2.1 & 2.6 \\
Molasses & 0.1 & 0.1 \\
Flavoring agent & 30.0 & 15.0 \\
Wheat straw & & \\
Chemical composition of postweaning diet & 21.1 & 25.0 \\
CP (\% of DM) & 46.0 & 30.1 \\
NDF (\% of DM) & 2.5 & 2.9 \\
ME (Mcal/kg of DM) & & \\
\hline
\end{tabular}

${ }^{1}$ Preweaning diet was fed between 1 and $50 \mathrm{~d}$ of age, followed by a weaning transition ( $10 \%$ daily reduction in milk offered) over $10 \mathrm{~d}$, with weaning occurring at $60 \mathrm{~d}$ of age.

${ }^{2}$ Postweaning diet was fed between 11 and 25 wk of age.

${ }^{3}$ Rumimax pellets (Trouw Nutrition, Guelph, ON, Canada) also contained straw. 
shavings and heifers were fed as per the assigned postweaning diet protocol with ad libitum access to water.

Blood samples were collected every $12 \mathrm{~min}$ for 10 $\mathrm{h}$ starting $3 \mathrm{~h}$ before the morning feeding. Between samples, the catheter was flushed with $1.5 \mathrm{~mL}$ of heparinized saline solution (2\%). Each sample was collected using a plastic syringe and transferred to a lithium heparin tube (BD Vacutainer, Franklin Lakes, $\mathrm{NJ}$ ), containing $0.5 \mu \mathrm{L}$ of aprotinin from bovine lung (Sigma, Oakville, ON, Canada) per mL of blood, and placed on ice until centrifugation $\left(20 \mathrm{~min}\right.$ at $4^{\circ} \mathrm{C}$ and $3,000 \times g)$, then plasma was harvested and stored at $-20^{\circ} \mathrm{C}$. Circulating plasma LH concentrations were quantified by a double-antibody radioimmunoassay validated for bovine plasma (Evans et al., 1992; Endocrine Lab Services, University of Saskatchewan, Saskatoon, SK, Canada). The inter- and intraassay coefficients of variation were $6.8 \%$ and $6.2 \%$, respectively.

Profiles of sequential LH concentrations of each sampling period were evaluated to determine the LH pulse threshold $(0.8 \mathrm{ng} / \mathrm{mL})$, calculated as the overall mean LH concentration plus 1 SD (Dyck et al., 2011). Luteinizing hormone release was characterized by the pulse frequency, amplitude, and duration (Figure 2). Pulse frequency was calculated as the number of times LH concentrations exceeded the pulse threshold within the 10-h sampling period. Pulse amplitude was determined as the difference between the maximum LH concentration within a pulse and the LH concentration imme- diately preceding the pulse onset. Pulse duration was estimated as the number of minutes with consecutive LH concentration samples above the pulse threshold.

\section{Determination of Age at Puberty}

Beginning at 26 wk of age until confirmation of puberty, heifers were weighed weekly and subjected to transrectal ultrasonography (Aloka 500V, Aloka Co. Ltd., Tokyo, Japan; equipped with a $7.5-\mathrm{MHz}$ linear array transrectal transducer) of ovarian structures, performed by one individual. Both ovaries were scanned in multiple planes, and puberty was declared when the first ovulation was confirmed by the presence of a visible corpus luteum in either ovary.

\section{Statistical Analyses}

Data were analyzed using SAS (Studio 3.8 Edition, SAS Institute Inc., Cary, NC) and descriptive statistics obtained using the MEANS procedure. Pearson correlation coefficients among variables of BW, leptin concentrations, LH pulse profiles measured at 12 and 25 wk of age, and age at puberty were calculated using the CORR procedure. Circulating leptin concentrations measured over time were analyzed as Gaussian distribution using the GLIMMIX procedure, with different models for the pre- and postweaning phases. The preweaning phase model included the fixed effects of preweaning dietary

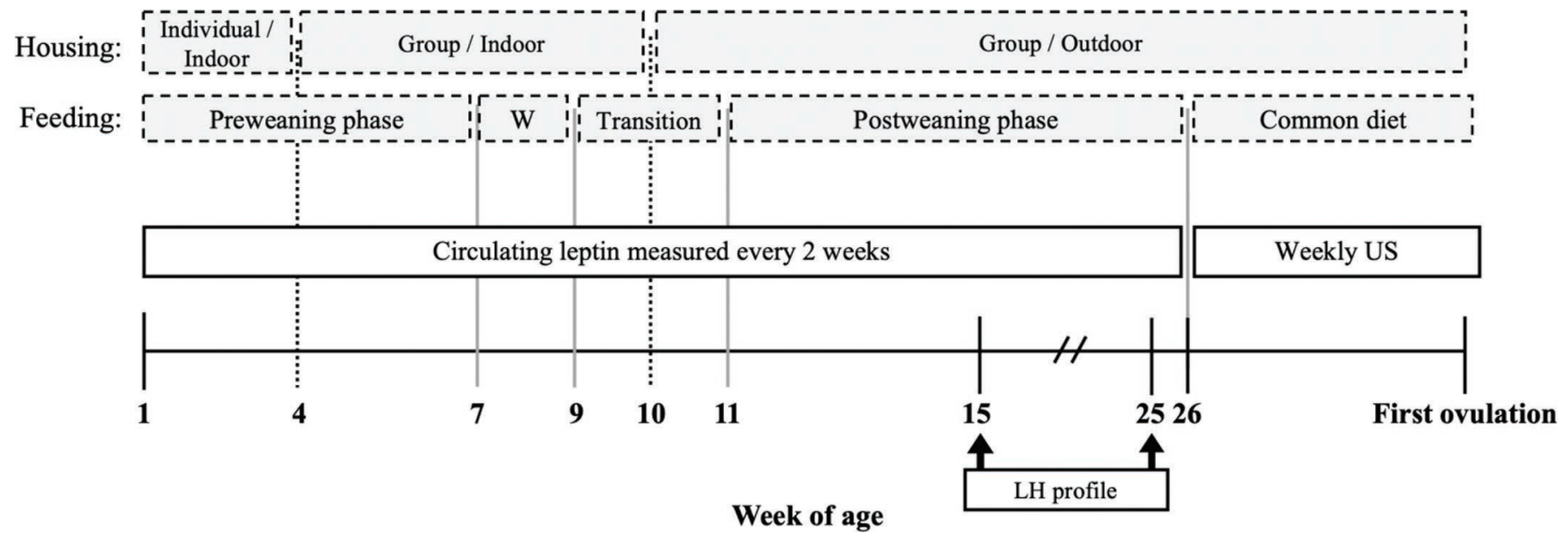

Figure 1. Schematic representation of study design. Holstein heifer calves $(\mathrm{n}=36)$ were randomly assigned to be fed either $5 \mathrm{~L}(\mathrm{n}=18)$ or $10 \mathrm{~L}(\mathrm{n}=18)$ of whole milk per day during the preweaning phase and a diet with either $70 \%(\mathrm{n}=18)$ or $85 \%(\mathrm{n}=18)$ of concentrate dry TMR during the postweaning phase. Weaning (W) occurred at $60 \mathrm{~d}$ of age by daily reduction in $10 \%$ of milk offered from 51 to $60 \mathrm{~d}$ of age, and a transition diet with $85 \%$ concentrate and $15 \%$ straw was offered from wk 9 to 11 of age. After the end of the postweaning phase (wk 26), heifers were fed a common diet with $2 \mathrm{~kg} / \mathrm{d}$ per heifer of a commercial ration with free access to alfalfa hay. Heifers had ad libitum access to water throughout the study period. From wk 1 to 25 , blood samples were taken once every 2 wk to quantify serum leptin concentrations. At both wk 15 and 25 of age, heifers were brought indoors and LH concentrations were quantified in sequential blood (plasma) samples. Starting in wk 26, heifers were subjected to weekly transrectal ultrasonography (US) of the ovaries until the first ovulation was confirmed (minimum to maximum; 26 to 52 wk of age) by the presence of a visible corpus luteum in either ovary, as an indication of puberty. 


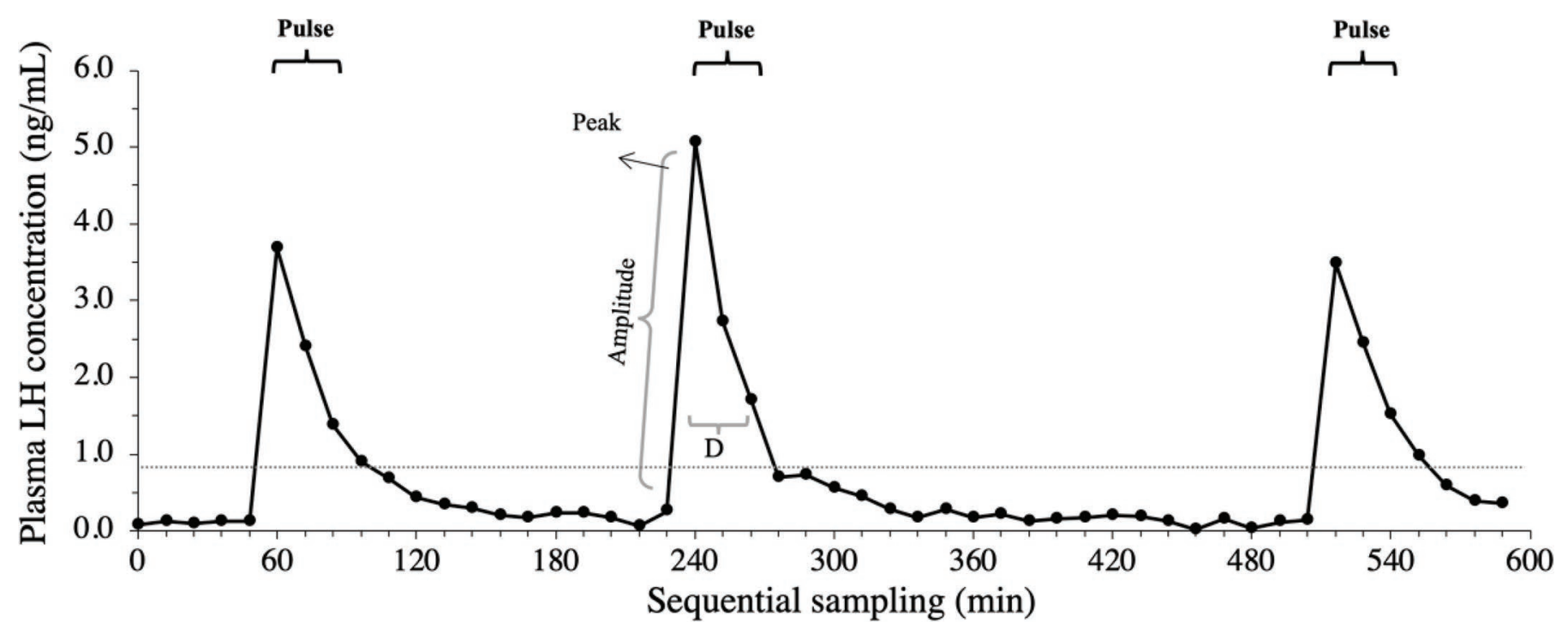

Figure 2. Characterization of variables of LH pulse profile of a hypothetical heifer as obtained by sequential blood (plasma) samples taken every 12 min over a 10-h sampling period in 36 Holstein heifers at 15 and 25 wk of age. The threshold for LH pulse (0.8 ng/mL; dotted line) was determined as the overall mean of LH concentration plus 1 SD. Pulse frequency was calculated as the number of LH pulses within the sampling period. Pulse amplitude was determined as the difference between the LH concentration peak (i.e., maximum LH concentration) within a pulse and the LH concentration immediately preceding the pulse. Pulse duration (D) was estimated as the total number of minutes that LH concentration remained above the threshold within a pulse.

treatment, age (wk 1 to 9 ), and interactions, with birth BW as a covariate and heifer as the repeated measures subject. The postweaning phase model included the fixed effects of pre- and postweaning treatments, age (wk 11 to 25), and interactions, with birth BW as a covariate and heifer as the subject of repeated measures. Interaction terms with $P>0.10$ were manually removed from the final model in a backward stepwise process, but the effects of pre- and postweaning treatments were deliberately kept. The covariance structure with the lowest Bayesian information criterion was chosen. In all models, normality and homoscedasticity of standardized residuals were assessed graphically, and if they were not met, data were investigated for potential outliers and logarithmic transformation was performed. Post-hoc tests were performed using Bonferroni adjustment.

Models evaluating the effects of dietary treatments on LH release variables followed a Gaussian (LH peak, amplitude, and duration) or Poisson distribution (LH frequency) and were built separately for each sampling period (at 15 and $25 \mathrm{wk}$ of age). The model for 15 wk of age sampling included the fixed effects of preweaning treatment, whereas the model for $25 \mathrm{wk}$ of age included the fixed effects of pre- and postweaning treatments and interactions, both with birth BW as a covariate and heifer as a random variable. The effects of dietary treatments on puberty were analyzed as either a Gaussian (age at puberty) or binomial distribution (attainment of puberty by $30 \mathrm{wk}$ ), including the fixed effects of pre- and postweaning treatments and interactions, with birth BW as a covariate. For linear models, residuals normality and homoscedasticity were assessed as previously described. Survival and hazard ratio analyses for age at puberty were conducted using the LIFETEST and PHREG procedures. Associations between attainment of puberty and BW, and retrospective leptin concentrations and LH profiles were also examined using linear models similar to those previously described. Results were reported as least squares means \pm standard error for normal data and as the backtransformed least squares means with their respective 95\% confidence interval for transformed data. For all statistical models, significances were declared at $P \leq$ 0.05 and tendencies at $P>0.05$ but $\leq 0.10$.

\section{RESULTS}

At the end of the treatment period at 25 wk of age, overall BW averaged $( \pm \mathrm{SE}) 247 \pm 3 \mathrm{~kg}$ and was greater in heifers offered the high compared with the low postweaning dietary treatment $(256 \pm 4$ vs. $238 \pm$ $4 \mathrm{~kg} ; P<0.01)$. Detailed data related to milk, starter, and energy intakes, measurements of body growth, and concentrations of key metabolites during both phases are presented in a companion paper (Rosadiuk et al., 2020). In brief, heifers offered the high preweaning dietary plane had greater milk intake, lower concentrate intake, and greater BW during the preweaning phase than those offered the low preweaning plane. Average 

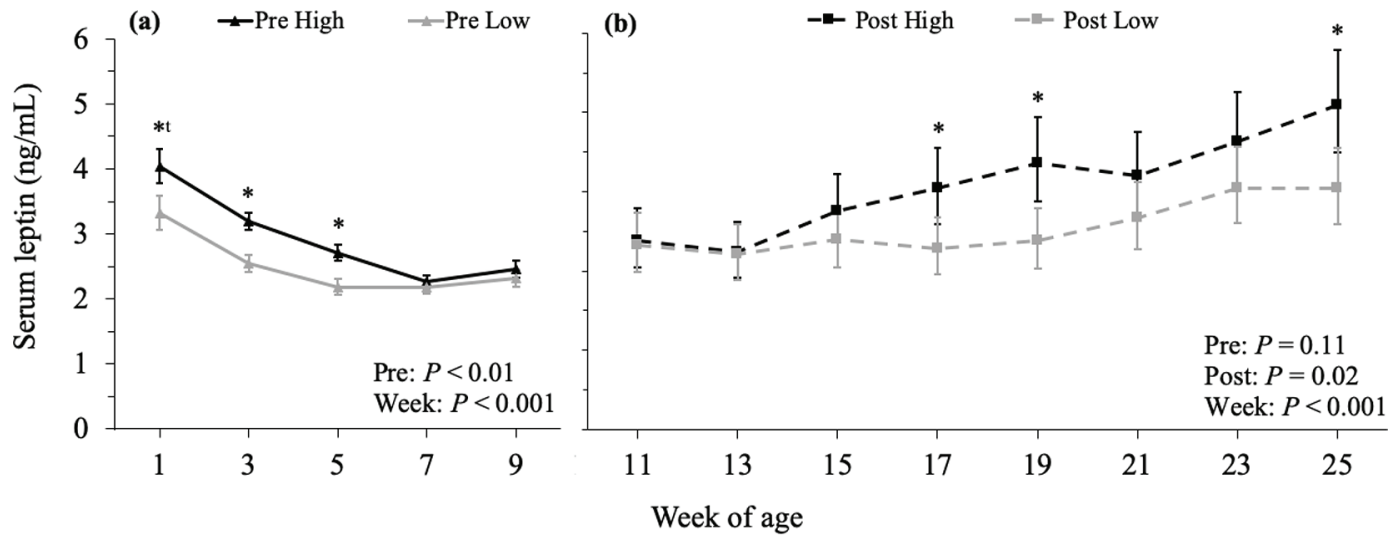

Figure 3. (a) Effects of preweaning dietary plane of nutrition [Pre High $(10 \mathrm{~L}$ of whole milk/d; $\mathrm{n}=18)$ vs. Pre Low $(5 \mathrm{~L}$ of whole milk/d; $\mathrm{n}=18)$ ] on serum leptin concentrations from 1 to 9 wk of age in 36 Holstein heifers. (b) Effects of pre- and postweaning [Post High (85\% of concentrate dry TMR; $\mathrm{n}=18$ ) vs. Post Low ( $70 \%$ of concentrate dry TMR; $\mathrm{n}=18)$ ] planes of nutrition on serum leptin concentrations from 11 to $25 \mathrm{wk}$ of age in 36 Holstein heifers. Error bars represent SEM in panel a and the 95\% CI of the back-transformed adjusted LSM in panel b. *Denotes significant differences $(P \leq 0.05)$ between dietary groups at individual time points. ${ }^{*}$ Denotes tendency $(P=0.06)$ for greater leptin concentration in wk 1 in heifers fed the high preweaning plane of nutrition.

daily gains for low and high preweaning plane heifers were $0.6 \pm 0.1$ and $0.8 \pm 0.1 \mathrm{~kg} / \mathrm{d}(P<0.001)$ during the preweaning phase, and the ADG during the postweaning phase were $1.3 \pm 0.1$ and $1.4 \pm 0.1 \mathrm{~kg} / \mathrm{d}(P<$ 0.01 ), respectively, for low and high postweaning plane heifers. During the postweaning phase, overall concentrate intake and $\mathrm{BW}$ were greater in heifers offered the high postweaning dietary plane than in those offered the low postweaning plane.

\section{Leptin Concentrations}

During the preweaning phase, serum leptin concentrations decreased over time $(P<0.001)$ and were affected by the preweaning dietary treatment $(P<0.01$; Figure 3a). Heifers offered the high preweaning diet had greater leptin concentration $(\mathrm{ng} / \mathrm{mL})$ than those offered the low preweaning diet at wk $1(4.0 \pm 0.3$ vs. $3.3 \pm 0.3 ; P=0.06), 3(3.2 \pm 0.1$ vs. $2.5 \pm 0.1$; $P<0.01), 5(2.7 \pm 0.1$ vs. $2.2 \pm 0.1 ; P<0.01)$, and overall $(2.9 \pm 0.1$ vs. $2.6 \pm 0.1 ; P<0.01)$. During the postweaning phase, leptin concentrations increased over time $(P<0.001)$ and were affected by postweaning diet $(P=0.02$; Figure $3 \mathrm{~b})$, although no effects of preweaning dietary treatment, or interactions between pre- and postweaning diets, were detected $(P=0.11$ and $P=0.20$, respectively). Heifers receiving the high postweaning diet had greater leptin concentrations $(\mathrm{ng} / \mathrm{mL})$ than those receiving the low postweaning diet at wk $17\{3.0$ [95\% confidence interval (CI) 2.6 to 3.6] vs. $2.3(95 \%$ CI 2.0 to 2.7$) ; P=0.01\}, 19$ [3.4 (95\% CI 2.9 to 3.9$)$ vs. 2.4 (95\% CI 2.0 to 2.8 ); $P<0.01$ ], 25 [4.1 (95\% CI 3.5 to 4.8 ) vs. 3.0 (95\% CI 2.6 to 3.6$) ; P<$
0.01], and overall [3.2 (95\% CI 2.7 to 3.4$)$ vs. 2.5 (95\% CI 2.3 to 2.8$) ; P=0.02$.

\section{Luteinizing Hormone Release}

Overall mean LH concentrations were greater at wk 25 than at wk $15(0.33 \pm 0.02$ vs. $0.25 \pm 0.02 \mathrm{ng} / \mathrm{mL}$; $P<0.01)$ but was not affected by dietary treatments at either sampling period. Heifers offered the high preweaning diet had greater LH pulse amplitude and peak, and greater duration of LH pulse at wk 15 compared with heifers offered the low preweaning diet (Table 2). Nonetheless, profiles of LH pulse release at wk 25 of age were neither affected by pre- or postweaning dietary plane nor by their interaction (Table 3 ).

\section{Age at Puberty}

Age at attainment of puberty averaged (mean $\pm \mathrm{SE}$ ) $250 \pm 9 \mathrm{~d}$ (minimum to maximum; 176 to $367 \mathrm{~d}$ ) and it was not influenced by birth BW, but for every 10 $\mathrm{kg}$ increase in $\mathrm{BW}$ at $25 \mathrm{wk}$ of age, age at puberty decreased by $13 \mathrm{~d}(95 \% \mathrm{CI}=5$ to $21 ; P<0.01)$. Average age at puberty was not affected by pre- $(P=0.73)$ or postweaning $(P=0.24)$ dietary planes, or by their interaction $(P=0.84)$. Age at puberty averaged $253 \pm$ 13 and $248 \pm 12 \mathrm{~d}$ for low and high preweaning diet groups, and $261 \pm 10$ and $239 \pm 14 \mathrm{~d}$ for low and high postweaning diet groups, respectively. The proportion of heifers that attained puberty by 30 wk of age was 25.6 and $31.5 \%$ for low and high preweaning dietary groups, and 16.6 and $44.4 \%$ for low and high postweaning diet groups, respectively. Preweaning diet did not 
Table 2. Effects of offering different preweaning planes of nutrition [low $(5 \mathrm{~L}$ of whole milk/d; $\mathrm{n}=18)$ vs. high $(10 \mathrm{~L}$ of whole milk/d; $\mathrm{n}=18)]$ on $\mathrm{LH}$ pulse variables (LSM $\pm \mathrm{SEM}$ ) at 15 wk of age in 36 Holstein heifers

\begin{tabular}{|c|c|c|c|}
\hline \multirow[b]{2}{*}{ Variable } & \multicolumn{2}{|c|}{ Preweaning plane } & \multirow[b]{2}{*}{$P$-value } \\
\hline & Low $(\mathrm{n}=18)$ & $\operatorname{High}(\mathrm{n}=18)$ & \\
\hline Frequency $^{1}$ (pulses/10 h) & $1.8 \pm 0.3$ & $1.6 \pm 0.2$ & 0.51 \\
\hline Duration $^{2}$ (min) & $28.7 \pm 2.0$ & $35.6 \pm 2.1$ & 0.02 \\
\hline Amplitude $^{3}(\mathrm{ng} / \mathrm{mL})$ & $1.7 \pm 0.1$ & $2.1 \pm 0.1$ & 0.05 \\
\hline Peak $(\mathrm{ng} / \mathrm{mL})$ & $1.8 \pm 0.1$ & $2.2 \pm 0.1$ & 0.03 \\
\hline
\end{tabular}

influence the odds of achieving puberty by 30 wk of age $(P=0.71)$, but heifers fed the high postweaning diet tended to have $40 \%$ greater odds $(\mathrm{OR}=1.4 ; 95 \% \mathrm{CI}$ $=0.8$ to $20.2 ; P=0.09$ ) of achieving puberty by $30 \mathrm{wk}$ than those fed the low postweaning diet. Likewise, the likelihood of achieving puberty by $30 \mathrm{wk}$ as determined by survival analysis was greater (hazard ratio $=3.8$; $95 \% \mathrm{CI}=1.0$ to $14.4 ; P=0.05)$ in the high than in the low postweaning diet group (Figure 4). No interaction between pre- and postweaning planes were observed on the odds of puberty onset by $30 \mathrm{wk}(P=0.67)$.

\section{Associations Among Leptin, Luteinizing Hormone, and Age at Puberty}

Circulating leptin concentrations both at wk 15 and 25 were linearly associated with age at puberty; whereas for every $1 \mathrm{ng} / \mathrm{mL}$ increase in circulating leptin at wk 15 and 25, age at puberty decreased by $22 \mathrm{~d}(95 \% \mathrm{CI}$ $=1$ to $44 ; P=0.04)$ and $13 \mathrm{~d}(95 \% \mathrm{CI}=1$ to $24 ; P=$ $0.03)$, respectively. Heifers attaining puberty by $30 \mathrm{wk}$ of age also had greater $(P<0.01)$ overall circulating leptin concentrations from wk 13 to 25 [3.0 (95\% CI $=2.7$ to 3.3$)$ vs. $2.6(95 \% \mathrm{CI}=2.4$ to 2.7$) \mathrm{ng} / \mathrm{mL}]$ than those with a later attainment of puberty, and this difference was evident during the postweaning phase (Figure 5). At either sampling period, no significant associations were observed between LH release variables and age at puberty.

\section{DISCUSSION}

The present study determined the effects of differing planes of pre- and postweaning phase nutrition on endocrine indicators related to reproductive development and onset of puberty in Holstein heifers. Circulating leptin concentrations had a noticeable decrease from wk 1 to 7 (Figure 3a). Kesser et al. (2017) noted a similar decrease in leptin concentrations in Holstein calves.
This could be explained by the elevated concentrations of leptin in the few weeks after calving resulting from the colostrum intake, as transfer of leptin from colostrum to the offspring has previously been documented in cattle (Kesser et al., 2017). Although equal volumes of colostrum were provided to both treatment groups in the present study, it is possible that early beneficial effects of the high plane of nutrition occurred, resulting in slightly greater leptin concentrations at wk 1 in the high preweaning diet group. Differences between preweaning diet treatments at wk 3 and 5 are in agreement with data from Brown et al. (2005), showing greater leptin concentrations before $8 \mathrm{wk}$ of age in heifers offered a preweaning diet with increased energy and protein con-

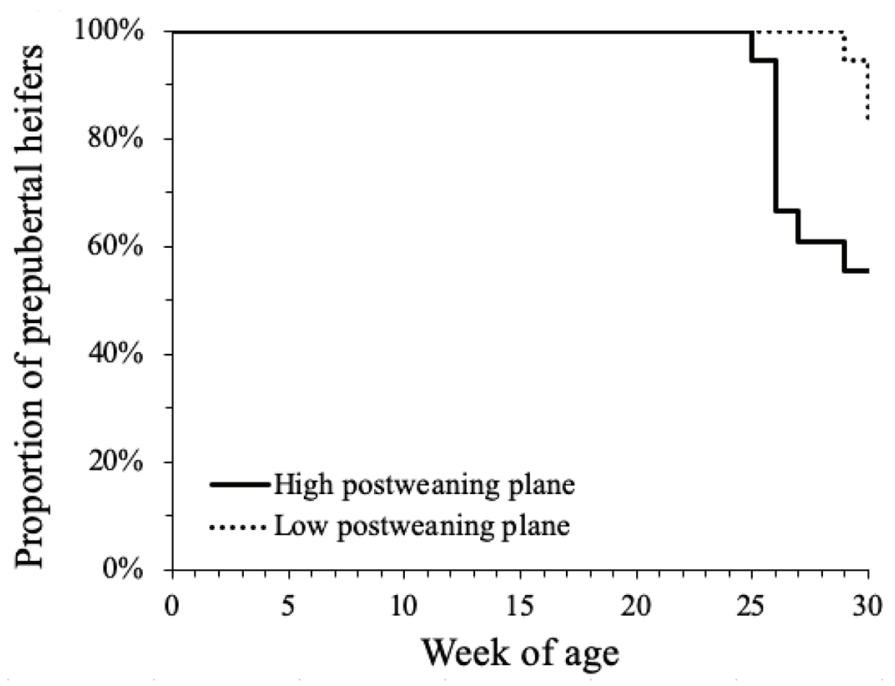

Figure 4. Survival curves of puberty by $30 \mathrm{wk}$ of age in 36 Holstein heifers fed either a high ( $85 \%$ of concentrate dry TMR; $n=18$ ) or low $(70 \%$ of concentrate dry TMR; $\mathrm{n}=18$ ) postweaning plane of nutrition from 11 to 25 wk of age. The likelihood of puberty by 30 wk of age was greater in heifers offered the high postweaning plane compared with heifers offered the low postweaning plane (hazard ratio $=3.7,95 \% \mathrm{CI}$ $=1.0$ to $13.9 ; P=0.05)$. 
Table 3. Effects of offering different preweaning [low $(5 \mathrm{~L}$ of whole milk/d; $\mathrm{n}=18)$ vs. high $(10 \mathrm{~L}$ of whole milk/d; $\mathrm{n}=18)]$ and postweaning [low $(70 \%$ of concentrate dry TMR; $\mathrm{n}=18)$ vs. high ( $85 \%$ of concentrate dry TMR; $\mathrm{n}=18)$ ] planes of nutrition on LH pulse variables $(\mathrm{LSM} \pm$ SEM) at 25 wk of age in 36 Holstein heifers

\begin{tabular}{|c|c|c|c|c|c|c|c|}
\hline Variable & \multicolumn{2}{|c|}{ Preweaning plane (Pre) } & \multicolumn{2}{|c|}{ Postweaning plane (Post) } & \multicolumn{3}{|c|}{$P$-value } \\
\hline 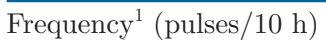 & $2.4 \pm 0.3$ & $2.1 \pm 0.3$ & $2.3 \pm 0.2$ & $2.2 \pm 0.3$ & 0.49 & 0.84 & 0.95 \\
\hline $\operatorname{Amplitude}^{3}(\mathrm{ng} / \mathrm{mL})$ & $1.7 \pm 0.2$ & $1.9 \pm 0.2$ & $1.8 \pm 0.2$ & $1.9 \pm 0.2$ & 0.44 & 0.92 & 0.87 \\
\hline Peak (ng/mL) & $1.9 \pm 0.2$ & $2.1 \pm 0.2$ & $2.0 \pm 0.2$ & $2.0 \pm 0.2$ & 0.57 & 0.91 & 0.97 \\
\hline
\end{tabular}

${ }^{1}$ Number of LH pulses within the 10-h sampling period. The threshold for LH pulse $(0.8 \mathrm{ng} / \mathrm{mL})$ was calculated as the overall mean of LH concentration plus $1 \mathrm{SD}$.

${ }^{2}$ Total number of minutes with LH concentration above the pulse threshold within a pulse.

${ }^{3}$ Difference between the LH concentration peak (i.e., maximum LH concentration) within a pulse and the LH concentration immediately preceding the pulse.

tents. The positive effect of increasing the postweaning plane of nutrition on serum leptin concentrations was evident starting at wk 17 (Figure 3b). This could be attributed to increased adipose tissue, as increasing the dietary energy and protein contents either during the preweaning (Bascom et al., 2007) or postweaning (Brown et al., 2005) phase resulted in greater body fat deposition. Chelikani et al. (2009) determined that BW and backfat thickness explained approximately $40 \%$ of the variation in leptin concentrations in growing heifers.

Increasing the preweaning plane of nutrition from 5 to $10 \mathrm{~L} / \mathrm{d}$ of whole milk resulted in greater $\mathrm{LH}$ pulse amplitude, LH peak, and LH pulse duration at $15 \mathrm{wk}$ of age. Although no treatment effects were observed on LH frequency, Gasser et al. (2006b) reported increased frequency of LH pulses in 24-h sampling periods in beef heifers offered postweaning diets with increased concentrate (60 vs. $30 \%$ corn). Such increase in LH pulse frequency was observed immediately preceding puberty but not from 14 to 24 wk of age (Gasser et al., 2006b). Specific factors that link increased nutritional plane and increased LH release are not fully understood. It is plausible to speculate that increased planes of nutrition would result in enhanced body growth, and consequently earlier onset of puberty, and therefore a detectable increase in LH pulse frequency as puberty approaches. However, in the present study, the postweaning diet plane did not affect LH pulse variables at wk 25. Furthermore, no associations between LH pulse characteristics and age at puberty were observed. In contrast, an early study (Day et al., 1987) reported a strong correlation between LH pulse frequency and age at puberty $(\mathrm{r}=0.88)$.

The lack of differences in LH profiles between high and low postweaning diet groups was likely because

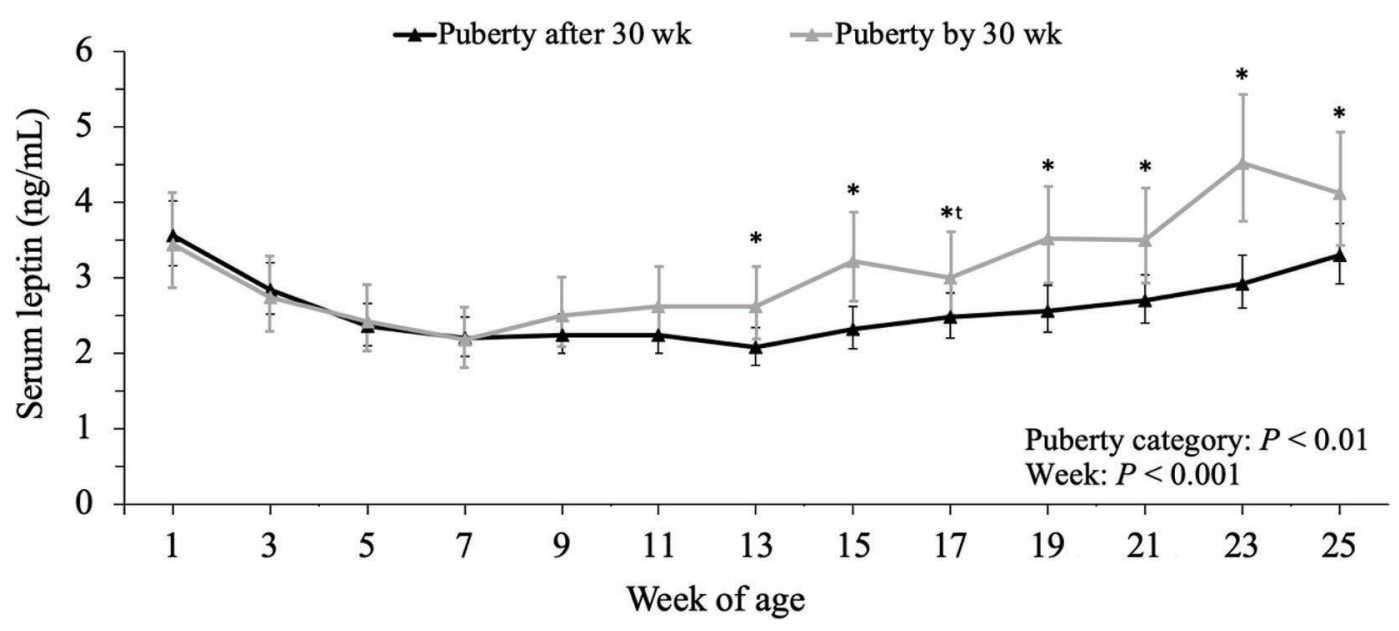

Figure 5. Retrospective serum leptin concentrations from 1 to $25 \mathrm{wk}$ of age in 36 Holstein heifers categorized as attaining puberty either before (gray line; $\mathrm{n}=11$ ) or after (black line; $\mathrm{n}=25) 30 \mathrm{wk}$ of age. Error bars represent the 95\% CI of the back-transformed adjusted LSM. *Denotes significant differences $(P \leq 0.05)$ between puberty categories at individual time points. ${ }^{* t}$ Denotes tendency $(P=0.08)$ for greater leptin concentration in wk 17 in heifers that attained puberty by 30 wk of age. 
both pre- and postweaning diets had relatively high energy and protein contents compared with previous studies (Brown et al., 2005; Gasser et al., 2006a), allowing for similar rates of reproductive development and LH release in both treatment groups. Therefore, providing postweaning planes of nutrition with greater differences in energy and protein content could enhance the ability to detect its potential effects on LH profiles around the time of puberty. Psychosocial stress associated with isolation and restraint (Tilbrook et al., 1999), and transport (Dobson et al., 1999) have been reported to reduce LH pulse amplitude and frequency in ewes. We believe that stress would not have played a role in affecting LH pulses in this study, as none of the heifers in the present study expressed any overt signs of stress during the 10-h period of sequential blood sampling. As described under methodology, heifers were moved as groups to the individual pen, had more than $12 \mathrm{~h}$ to adapt to the temporary individual pens, and were continuously able to have social interactions with each other.

No overall difference in age at puberty was observed due to differences in either the pre- or postweaning diets in this study. These results somewhat contradict previous literature, as multiple studies have demonstrated an overall decreased age at puberty when higher plane diets were fed (Chelikani et al., 2003; Shamay et al., 2005; Gasser et al., 2006a; Davis Rincker et al., 2011). For instance, Shamay et al. (2005) reported earlier puberty (258 vs. $286 \mathrm{~d}$ of age) in calves that were fed ad libitum whole milk (5.3 Mcal of ME/d and $27.0 \% \mathrm{CP}$ ) compared with $5 \mathrm{~L}$ of milk replacer $(4.1 \mathrm{Mcal}$ of $\mathrm{ME} / \mathrm{d}$ and $23.0 \% \mathrm{CP}$ ). Interestingly, heifers in the current study attained puberty at a younger age than in other reports (Chelikani et al., 2003; Shamay et al., 2005; Davis Rincker et al., 2011). As previous studies evaluating effects of milk regimens on age at puberty compared either whole milk versus milk replacer (Shamay et al., 2005) or different milk replacer formulations (Davis Rincker et al., 2011), it is reasonable to speculate that certain factors contained in whole milk, fed to all heifers in the present study, might have promoted an earlier attainment of puberty.

Regarding the postweaning phase diet, Gasser et al. (2006a) reported decreased age at puberty (262 vs. 368 d) in beef heifers that received diets with increased energy (2.0 vs. $1.7 \mathrm{Mcal} / \mathrm{kg}$, but similar CP at $14.1 \%$ ) from 18 to 28 wk of age. However, in the present study, survival analysis revealed that heifers receiving the high postweaning plane diet had greater likelihood of attaining puberty by $30 \mathrm{wk}$ than those receiving the lower plane (Figure 4). It is noteworthy that both postweaning dietary groups in the present study had relatively high overall growth rates (ADG) from 2 to
6 mo of age $(1.3 \pm 0.1$ and $1.4 \pm 0.1 \mathrm{~kg} / \mathrm{d}$ for low and high postweaning diet groups), which could partially explain the lack of significant treatment effects on age at puberty. For instance, Chelikani et al. (2003) reported that Holstein heifers fed for a high versus low ADG (1.0 vs. $0.5 \mathrm{~kg} \mathrm{BW/d}$ ) had an earlier onset of puberty (9 vs. 16 mo of age, respectively). Compared with previous studies that based their dietary treatments on NRC (2001) estimates (Chelikani et al., 2009; Quigley et al., 2019), in the present study, heifers in the low postweaning dietary plane had greater protein and total calories intake per day (reported in Rosadiuk et al., 2020). Therefore, the terms "low" and "high" used to categorize the postweaning dietary planes in the present study should be cautiously interpreted and not generalized, as we observed a relatively higher BW at wk $25(247 \mathrm{~kg})$ than in other reports (Shamay et al., 2005; Davis Rincker et al., 2011), of approximately 200 $\mathrm{kg}$ of BW. Heifers fed the low postweaning diet had lower mean BW and heart girth during the postweaning period than those fed the high postweaning diet, but postweaning diet did not influence withers height (Rosadiuk et al., 2020).

A high variation in age at attainment of puberty was observed (176 to $367 \mathrm{~d}$ ), which was possibly influenced by seasonality. The preweaning environment was identical for all calves as they were born and raised indoors in a temperature-controlled barn with common lighting patterns. However, once weaned, calves were moved to outdoor paddocks exposing them to natural variations in photoperiod and temperature. A post-hoc analysis determined that heifers reaching 6 mo of age during winter attained puberty at an older age $(291 \pm 15 \mathrm{~d})$ than those reaching 6 mo of age during summer (234 $\pm 18 \mathrm{~d})$ or fall $(235 \pm 11 \mathrm{~d} ; P=0.01)$. These findings should be interpreted cautiously as this study was not designed to assess effects of season on age at puberty; nonetheless, they agree with Hansen et al. (1983) who reported reduced age at puberty in heifers exposed to a longer photoperiod after 22 or 24 wk of age. As previously mentioned, calves in the present study within each dietary treatment group were similarly distributed among season of birth, so seasonality might have not confounded the association between dietary treatment and onset of puberty.

The association observed between serum leptin concentrations before wk 25 and onset of puberty is possibly explained by the link between body fat deposition, circulating leptin, and sexual development [reviewed by Zieba et al. (2005)]. In this regard, broiler breeder pullets fed a high- compared with a low-energy diet had greater body lipid deposition and advanced sexual development through earlier onset of lay and greater concentrations of LH, FSH, and 17- $\beta$-estradiol (Hadinia 
et al., 2020). In the current study, serum leptin concentrations before $13 \mathrm{wk}$ of age were similar between heifers that attained puberty before or after $30 \mathrm{wk}$ of age. However, circulating leptin increased linearly beyond wk 13 and was greater in heifers that attained puberty by 30 wk than those attaining a later puberty (Figure 5). Linear increases in leptin concentrations in the peripubertal period have been noted in some studies (Díaz-Torga et al., 2001; Garcia et al., 2002), but not others (Block et al., 2003; Chelikani et al., 2009). Here, the relationship between relative age at puberty and leptin concentrations before 25 wk of age supports the concept that leptin might play a role in the cascade of events necessary for puberty to be attained. Chelikani et al. (2009) found no evidence of a peripubertal increase in leptin concentrations for heifers grown for a targeted ADG of $1.1 \mathrm{~kg}$ of $\mathrm{BW} / \mathrm{d}$, but they did find such an increase for groups fed for a target of 0.5 and $0.8 \mathrm{~kg}$ of BW/d. Similarly, Block et al. (2003) reported an increase in leptin in the peripubertal period for heifers attaining a later puberty (at $414 \mathrm{~d}$ ) but not in those attaining puberty at a younger age (at $286 \mathrm{~d}$ ). However, comparisons between studies are limited due to different stages in life at which circulating leptin was quantified. Future research should consider factors influencing leptin concentrations during the peripubertal period.

Increasing the preweaning dietary plane from 5 to $10 \mathrm{~L} / \mathrm{d}$ of whole milk increased circulating leptin concentrations and enhanced LH pulses at wk 15 of age. Increasing the postweaning dietary plane from 70 to $85 \%$ of concentrate dry TMR resulted in greater leptin concentrations by wk 25, which was also associated with an earlier onset of puberty. A study conducted in conjunction with the current study evaluating the same heifers reported positive effects of increasing the pre- and postweaning planes of nutrition on indicators of reproductive development, such as endometrial thickness and number of follicles (Bruinjé et al., 2019). These findings indicate that increasing the nutritional plane can result in enhanced endocrine profiles associated with reproductive development.

\section{CONCLUSIONS}

Providing increased planes of nutrition during the preweaning (10 vs. 5 L of milk/d) and postweaning ( 85 vs. $70 \%$ concentrate dry TMR) phases resulted in greater circulating leptin concentrations during both phases. Heifers offered the increased preweaning plane also had enhanced LH pulses at 15 wk of age, but LH release was not affected by the postweaning plane. Age at puberty was not influenced by the preweaning plane, but heifers offered the increased postweaning plane were more likely to have an earlier onset of puberty. Find- ings imply that increasing the pre- and postweaning nutritional planes can enhance endocrine profiles, such as increasing leptin concentrations, associated with an early onset of puberty. Enhanced endocrine profiles and early onset of puberty can have positive effects on heifer reproductive performance at the initiation of the breeding program.

\section{ACKNOWLEDGMENTS}

This research was supported by Alberta Livestock and Meat Agency and Alberta Milk (Edmonton, AB, Canada). The authors thank Trouw Animal Nutrition (Guelph, ON, Canada) for donating the feed, Darrell Bignell of Alberta Agriculture and Forestry (Edmonton, AB, Canada) and all the student volunteers that provided technical assistance during the study, and Thomas Blees (University of Bonn, Germany) for performing the leptin ELISA tests. M. A. Steele's position was supported by Alberta Milk (Edmonton, AB, Canada), BC Dairy Association (Burnaby, BC, Canada), Dairy Farmers of Manitoba (Winnipeg, MB, Canada), Lallemand Animal Nutrition (Montreal, QC, Canada), Trouw Animal Nutrition (Guelph, ON, Canada), SaskMilk (Regina, SK, Canada), Westgen (Abbotsford, BC, Canada), and National Science and Engineering Research Council (Ottawa, ON, Canada). The authors declare no conflicts of interest.

\section{REFERENCES}

Bascom, S. A., R. E. James, M. L. McGilliard, and M. Van Amburgh. 2007. Influence of dietary fat and protein on body composition of Jersey bull calves. J. Dairy Sci. 90:5600-5609. https://doi.org/10 $.3168 /$ jds.2007-0004.

Block, S. S., J. M. Smith, R. A. Ehrhardt, M. C. Diaz, R. P. Rhoads, M. E. Van Amburgh, and Y. R. Boisclair. 2003. Nutritional and developmental regulation of plasma leptin in dairy cattle. J. Dairy Sci. 86:3206-3214. https://doi.org/10.3168/jds.S0022 $-0302(03) 73923-X$.

Brown, E. G., M. J. Vandehaar, K. M. Daniels, J. S. Liesman, L. T. Chapin, D. H. Keisler, and M. S. W. Nielsen. 2005. Effect of increasing energy and protein intake on body growth and carcass composition of heifer calves. J. Dairy Sci. 88:585-594. https://doi .org/10.3168/jds.S0022-0302(05)72722-3.

Bruinjé, T. C., J. P. Rosadiuk, F. Moslemipur, J. E. Carrelli, M. A. Steele, and D. J. Ambrose. 2019. Carryover effects of pre- and postweaning planes of nutrition on reproductive tract development and estrous cycle characteristics in Holstein heifers. J. Dairy Sci. 102:10514-10529. https://doi.org/10.3168/jds.2019-16249.

Byerley, D. J., R. B. Staigmiller, J. G. Berardinelli, and R. E. Short 1987. Pregnancy rates of beef heifers bred either on puberal or third estrus. J. Anim. Sci. 65:645-650. https://doi.org/10.2527/ jas1987.653645x.

Canwest DHI. 2018. 2018 Herd management benchmarks report. Accessed Oct. 16, 2020. http://www.canwestdhi.com/pdf_files/2018 benchmarks/2018 canada Benchmarks english.pdf.

Chelikani, P. K., D. J. Ambrose, D. H. Keisler, and J. J. Kennelly, 2009. Effects of dietary energy and protein density on plasma concentrations of leptin and metabolic hormones in dairy heifers. J. Dairy Sci. 92:1430-1441. https://doi.org/10.3168/jds.2008-1385. 
Chelikani, P. K., J. D. Ambrose, and J. J. Kennelly. 2003. Effect of dietary energy and protein density on body composition, attainment of puberty, and ovarian follicular dynamics in dairy heifers. Theriogenology 60:707-725. https://doi.org/10.1016/S0093 $-691 \mathrm{X}(03) 00088-8$

Davis Rincker, L. E., M. J. VandeHaar, C. A. Wolf, J. S. Liesman, L. T. Chapin, and M. S. Weber Nielsen. 2011. Effect of intensified feeding of heifer calves on growth, pubertal age, calving age, milk yield, and economics. J. Dairy Sci. 94:3554-3567. https://doi.org/ $10.3168 /$ jds.2010-3923.

Day, M. L., K. Imakawa, P. L. Wolfe, R. J. Kittok, and J. E. Kinder. 1987. Endocrine mechanisms of puberty in heifers. Role of hypothalamo-pituitary estradiol receptors in the negative feedback of estradiol on luteinizing hormone secretion. Biol. Reprod. 37:10541065. https://doi.org/10.1095/biolreprod37.5.1054.

Díaz-Torga, G. S., M. E. Mejía, A. González-Iglesias, N. Formía, D. Becú-Villalobos, and I. M. Lacau-Mengido. 2001. Metabolic cues for puberty onset in free grazing Holstein heifers naturally infected with nematodes. Theriogenology 56:111-122. https://doi.org/10 1016/S0093-691X(01)00547-7.

Dobson, H., J. E. Tebble, J. B. Phogat, and R. F. Smith. 1999. Effect of transport on pulsatile and surge secretion of LH in ewes in the breeding season. J. Reprod. Fertil. 116:1-8. https://doi.org/10 $.1530 /$ jrf.0.1160001

Dyck, B. L., M. G. Colazo, D. J. Ambrose, M. K. Dyck, and L. Doepel. 2011. Starch source and content in postpartum dairy cow diets: Effects on plasma metabolites and reproductive processes. J. Dairy Sci. 94:4636-4646. https://doi.org/10.3168/jds.2010-4056.

Evans, A. C., W. D. Currie, and N. C. Rawlings. 1992. Effects of naloxone on circulating gonadotrophin concentrations in prepubertal heifers. J. Reprod. Fertil. 96:847-855. https://doi.org/10.1530/jrf 0.0960847

Freetly, H. C., L. A. Kuehn, and L. V. Cundiff. 2011. Growth curves of crossbred cows sired by Hereford, Angus, Belgian Blue, Brahman, Boran, and Tuli bulls, and the fraction of mature body weight and height at puberty. J. Anim. Sci. 89:2373-2379. https://doi.org/10 $.2527 /$ jas.2011-3847.

Garcia, M. R., M. Amstalden, S. W. Williams, R. L. Stanko, C. D. Morrison, D. H. Keisler, S. E. Nizielski, and G. L. Williams. 2002. Serum leptin and its adipose gene expression during pubertal development, the estrous cycle, and different seasons in cattle. J. Anim. Sci. 80:2158-2167. https://doi.org/10.2527/2002.8082158x.

Gasser, C. L., E. J. Behlke, D. E. Grum, and M. L. Day. 2006a. Effect of timing of feeding a high-concentrate diet on growth and attainment of puberty in early-weaned heifers. J. Anim. Sci. 84:3118 3122. https://doi.org/10.2527/jas.2005-676.

Gasser, C. L., D. E. Grum, M. L. Mussard, F. L. Fluharty, J. E. Kinder, and M. L. Day. 2006b. Induction of precocious puberty in heifers I: Enhanced secretion of luteinizing hormone. J. Anim. Sci. 84:2035-2041. https://doi.org/10.2527/jas.2005-636.

Groen, M. J., M. A. Steele, and T. J. DeVries. 2015. Short communication: Effect of straw inclusion rate in a dry total mixed ration on the behavior of weaned dairy calves. J. Dairy Sci. 98:2693-2700. https://doi.org/10.3168/jds.2014-8978.

Hadinia, S. H., P. R. O. Carneiro, C. J. Fitzsimmons, G. Y. Bédécarrats, and M. J. Zuidhof. 2020. Post-photostimulation energy intake accelerated pubertal development in broiler breeder pullets. Poult. Sci. 99:2215-2229. https://doi.org/10.1016/j.psj.2019.11.065.

Hansen, P. J., L. A. Kamwanja, and E. R. Hauser. 1983. Photoperiod influences age at puberty of heifers. J. Anim. Sci. 57:985-992. https://doi.org/10.2527/jas1983.574985x.

Heinrichs, A. J., G. I. Zanton, G. J. Lascano, and C. M. Jones. 2017. A 100-Year Review: A century of dairy heifer research. J. Dairy Sci. 100:10173-10188. https://doi.org/10.3168/jds.2017-12998.

Kesser, J., M. Korst, C. Koch, F. J. Romberg, J. Rehage, U. Müller, M. Schmicke, K. Eder, H. M. Hammon, H. Sadri, and H. Sauerwein. 2017. Different milk feeding intensities during the first 4 weeks of rearing dairy calves: Part 2: Effects on the metabolic and endocrine status during calfhood and around the first lactation. J. Dairy Sci. 100:3109-3125. https://doi.org/10.3168/jds.2016-11595.
Khan, M. A., A. Bach, D. M. Weary, and M. A. G. von Keyserlingk. 2016. Invited review: Transitioning from milk to solid feed in dairy heifers. J. Dairy Sci. 99:885-902. https://doi.org/10.3168/jds.2015 $-9975$.

Khan, M. A., D. M. Weary, and M. A. G. von Keyserlingk. 2011. Invited review: Effects of milk ration on solid feed intake, weaning, and performance in dairy heifers. J. Dairy Sci. 94:1071-1081. https://doi.org/10.3168/jds.2010-3733.

NRC. 2001. Nutrient Requirements of Dairy Cattle. 7th rev. ed. Natl. Acad. Sci., Washington, DC.

Perry, G. A. 2016. Factors affecting puberty in replacement beef heifers. Theriogenology 86:373-378. https://doi.org/10.1016/j theriogenology.2016.04.051.

Quigley, J. D., W. Hu, J. R. Knapp, T. S. Dennis, F. X. Suarez-Mena, and T. M. Hill. 2019. Estimates of calf starter energy affected by consumption of nutrients. 2. Effect of changing digestion on energy content in calf starters. J. Dairy Sci. 102:2242-2253. https://doi .org/10.3168/jds.2018-15354.

Radcliff, R. P., M. J. Vandehaar, L. T. Chapin, T. E. Pilbeam, D. K. Beede, E. P. Stanisiewski, and H. A. Tucker. 2000. Effects of diet and injection of bovine somatotropin on prepubertal growth and first-lactation milk yields of Holstein cows. J. Dairy Sci. 83:23-29. https://doi.org/10.3168/jds.S0022-0302(00)74850-8.

Rosadiuk, J. P., T. C. Bruinjé, F. Moslemipur, A. J. Fischer-Tlustos, D. J. Ambrose, and M. A. Steele. 2020. Differing planes of preand postweaning phase nutrition in Holstein heifers: I. Effects on feed intake, growth efficiency, and metabolic and development indicators. J. Dairy Sci. 103:1136-1152. https://doi.org/10.3168/jds .2020-18809.

Sauerwein, H., U. Heintges, M. Hennies, T. Selhorst, and A. Daxenberger. 2004. Growth hormone induced alterations of leptin serum concentrations in dairy cows as measured by a novel enzyme immunoassay. Livest. Prod. Sci. 87:189-195. https://doi.org/10 .1016/j.livprodsci.2003.08.001.

Shamay, A., D. Werner, U. Moallem, H. Barash, and I. Bruckental. 2005. Effect of nursing management and skeletal size at weaning on puberty, skeletal growth rate, and milk production during first lactation of dairy heifers. J. Dairy Sci. 88:1460-1469. https://doi .org/10.3168/jds.S0022-0302(05)72814-9.

Tilbrook, A. J., B. J. Canny, M. D. Serapiglia, T. J. Ambrose, and I. J. Clarke. 1999. Suppression of the secretion of luteinizing hormone due to isolation/restraint stress in gonadectomised rams and ewes is influenced by sex steroids. J. Endocrinol. 160:469-481. https:// doi.org/10.1677/joe.0.1600469.

USDA. 2009. Reproduction practices on U.S. dairy operations, 2007. Animal and Plant Health Inspection Service (APHIS), Fort Collins, CO.

Zieba, D. A., M. Amstalden, S. Morton, M. N. Maciel, D. H. Keisler, and G. L. Williams. 2004. Regulatory roles of leptin at the hypothalamic-hypophyseal axis before and after sexual maturation in cattle. Biol. Reprod. 71:804-812. https://doi.org/10.1095/ biolreprod.104.028548.

Zieba, D. A., M. Amstalden, and G. L. Williams. 2005. Regulatory roles of leptin in reproduction and metabolism: A comparative review. Domest. Anim. Endocrinol. 29:166-185. https://doi.org/10 .1016/j.domaniend.2005.02.019.

\section{ORCIDS}

T. C. Bruinjé @ https://orcid.org/0000-0003-4046-8081

J. P. Rosadiuk (®) https://orcid.org/0000-0003-2410-5758

F. Moslemipur (ㄴ) https://orcid.org/0000-0002-3717-7227

H. Sauerwein (ㄴ) https://orcid.org/0000-0002-6905-4053

M. A. Steele @ https://orcid.org/0000-0001-6941-6205

D. J. Ambrose @ https://orcid.org/0000-0002-3313-7199 